KENOSIS : JURNAL KAJIAN TEOLOGI

ISSN 2460-6901(Print), 2656-4483 (Online)

https://e-journal.iaknambon.ac.id/index.php/KNS

DOI: $10.37196 /$ kenosis.v7i2.253

\title{
SEKULARISASI, KULTUR DIGITAL DAN GELIAT AGAMA: Tantangan dan Sketsa Berteologi Digital di Indonesia
}

\section{Bobby Daniel Nalle}

\author{
Fakultas Teologi \\ Universitas Kristen Artha Wacana \\ Jl. Adi Sucipto No.147, Oesapa, Klp. Lima, Kota Kupang, \\ Nusa Tenggara Timur \\ bobbydnalle@yahoo.com
}

\begin{abstract}
Secularization and digital culture are the influencing aspects that define the characteristics of religious societies in the 21st century. As a formation of the history of social change, these two elements greatly determine the efforts of religion, in doing theology and church services at the present, in the term of digital theology. Indeed, It is determined by the surprising rise of the COVID-19 pandemic which forces religious efforts to deal with digital things. As a new experience, digital theology seeks a form as to how the social change made it. Elements such as secularization, digital culture, and church formation become the important aspects to determine the direction of doing theology. Based on these new experiences, this paper will describe a sketch of how to doing digital theology in Indonesia, especially in the case of GMIT. With the theology of incarnation as the frame, digital theology puts the relational substance (God-human, among human relationships and between the real and digital world. As the digital world as a locus, digital theology therefore over a liquid digital church and the presensia-accompaniment model of a church mission to be the sketch of doing theology in the digital context in Indonesia.
\end{abstract}

Keywords: Secularization, digital culture, incarnation theology, relational theology, liquid-digital church, Presensia mission \& Accompaniment 


\begin{abstract}
Abstrak
Sekularisasi dan kultur digital adalah dua elemen yang berpengaruh dalam ciri keberagamaan masyarakat religius di abad ke 21. Sebagai bentukan dari sejarah perubahan sosial, kedua hal ini sangat menentukan upaya beragama, berteologi dan bergereja dalam konteks kekinian. Salah satu istilah yang dikedepankan adalah teologi digital. Bentuk berteologi digital saat ini justru didorong oleh situasi pandemi COVID-19. Sebagai sebuah pengalaman dadakan dan baru berteologi secara digital menjadi upaya mencari bentuk mengikuti perubahan sosial Elemen seperti sekularisasi dan kultur digital dan geliat beragama menjadi aspek yang menentukan arah berteologi. Dengan berpatokan pada pengalaman baru inilah tulisan ini berkenan memberikan gambaran sketsa berteologi digital di Indonesia melalui pengalaman bergereja di GMIT. Payung teologi inkarnasi yang dipakai sebagai usulan berteologi, mendasari keterkaitan relasional baik antara Allah dan manusia, antar-manusia maupun antara dunia real dan digital. Dalam memaknai ruang digital menjadi locus berteologi, maka sketsa gereja cair digital, dan model kehadiran digital presensia dan accompaniment menjadi sebuah tawaran bergereja dan bermisi dalam konteks digital di Indonesia.
\end{abstract}

Kata Kunci: Sekularisasi, kultur digital, teologi inkarnasi, teologi relasional, gereja cair-digital, misi Presensia \& Accompaniment.

\title{
PENDAHULUAN
}

Topik teologi digital mengemuka mengikuti perubahan sosial budaya dan teknologi yang berkembang dalam masyarakat. Aspek-aspek seperti sekularisasi, kultur digital menuntut geliat agama dan juga gereja dalam merespons perkembangan peradaban. Topik ini sesuatu yang cukup luas. Bahkan dunia cyber atau digital itu sendiri memiliki dimensi yang luas, apalagi jika dipahami dalam kaitan sebagai kultur yang dibentuk oleh pergeseran tradisi, dari lisan ke tulisan hingga ke digital. Namun menghadapi dan berinteraksi dengan realitas baru adalah bagian dari komunikasi itu sendiri. Karena itu pemanfaatannya juga akan dilihat dalam rangka memberi informasi kepada kita tentang "realitas" digital itu sendiri. Artikel ini mengangkat konteks digital di Indonesia sebagai realitas baru yang perlu direspons dan selanjutnya berupaya membangun sebuah teologi dengan realitas dimaksud.

Tentulah memetakan dan mendeskripsikan konteks digital yang berkaitan dengan upaya berteologi ini membutuhkan catatan yang komprehensif dan memadai dari berbagai aspek kehidupan masyarakat Indonesia. Elemen seperti sekularisasi dan kultur digital perlu sedikit dielaborasi mengingat pengaruhnya dalam realitas digital yang sedang berjalan dalam masyarakat Indonesia juga. Namun dengan situasi khusus 
pandemi Covid 19, tulisan ini terbantu dengan informasi pemanfaatan teknologi digital dalam pelayanan gereja-gereja di Indonesia. Tulisan ini akan lebih terfokus pada refleksi atas pengalaman bergereja digital termasuk bergereja secara "online", dan respons jemaat yang memunculkan pokok-pokok pemahaman substansial berkaitan dengan pemanfaatan teknologi digital, yang mewujud dan mencuat dalam pertanyaan-pertanyaan teologis dari pengalaman bergereja online. Secara khusus pengalaman bergereja online digital yang disoroti adalah sebagaimana yang dijalani oleh Gereja Masehi Injili di Timor (GMIT).

Perkembangan peradaban dan teknologi telah membawa masyarakat Indonesia memasuki era digital. Istilah digital adalah salah satu istilah untuk menggambarkan situasi perkembangan teknologi; dari teknologi mekanik dan analog ke bentuk digital. Istilah ini sering juga dipahami sebagai kemajuan teknologi komputer, informatika, internet dan digital. Beberapa istilah yang sepadan sering digunakan untuk menjelaskan situasi yang sama ialah cyber atau online/daring. Klaus Schwab menempatkan pergeseran perkembangan teknologi ini dalam kaitan dengan Revolusi Industri 4.0. ${ }^{1}$ Schwab menjelaskan tentang dampak Revolusi Industri 4.0 yang sangat mencolok dalam beberapa bidang. Di bidang ekonomi, dampak terkuat pada aspek lapangan pekerjaan dan hakikat kerja. Dengan kemajuan teknologi digital dan robotic nampaknya banyak pekerjaan yang dapat digantikan oleh teknologi ini. Efisiensi yang diciptakan oleh teknologi digital semakin hari semakin mengurangi peran manusia dalam mengerjakan hal-hal teknis. ${ }^{2}$ Di bidang bisnis, bermunculan model-model baru bisnis yang didukung dengan data dan bentuk operasional digital yang baru termasuk bisnis online. Syarat kemampuan digital menjadi mutlak dalam mengembangkan bisnis baru. Menarik bahwa kenyataan ini semakin nampak dalam masa pandemi COVID-19, salah satu contoh yang mencuat tatkala kebijakan social distancing adalah bertambah dan meningkatnya bisnis online di Indonesia hingga mencapai $400 \% .^{3}$

Dalam bidang Nasional dan Global, Schwab menggambarkan nilai akuntabilitas dan keamanan pelayanan menjadi perhatian penting, karena di balik pemanfaatan teknologi digital masalah keamanan turut menjadi perhatian. Sisi teknologi yang memiliki ekses penyalahgunaan atau penggunaan secara tidak benar dapat saja menjadi ancaman tersendiri. Dalam bidang kemasyarakatan, Schwab 
melihat level ketimpangan sosial juga meningkat, meliputi ketimpangan pendapatan, pengangguran yang berisiko pada ketidakstabilan sosial. Kerentanan ada pada kelas menengah tatkala ekonomi pasar dapat saja menyingkirkan kelas menengah yang tidak mampu menguasai pasar. ${ }^{4}$ Makna komunitas juga mulai bergeser untuk kepentingan individu, seperti komunitas-komunitas online. Menurut perkembangan budaya populer, perilaku pasar yang konsumtif dan cenderung jatuh pada konsumerisme turut membentuk polarisasi sosial. Dalam aspek hubungan individu, Schwab menguraikan ada tiga hal pokok terkait dengan individu di era digital yakni persoalan identitas serta moralitas dan etika. Ruang digital sebagai tempat kecerdasan artifisial bertumbuh, dapat saja menentukan identitas dan moralitas. Selain itu, relasi individu diperdalam dengan teknologi sehingga berdampak pada sisi sosial dan empati manusia. Tantangan besar yang dihadirkan oleh teknologi digital bagi masyarakat maupun gereja adalah persoalan bagaimana mengatur informasi publik dan privat seseorang serta menyiasati kesenjangan komunikasi dan informasi pada tataran masyarakat maupun jemaat.

Perkembangan masyarakat Indonesia menjadi masyarakat digital selintas tergambar dalam riset mengenai pemanfaatan teknologi digital. Sebagaimana dilansir oleh Tomato Digital Indonesia, dengan populasi pada Januari 2019 berjumlah kurang lebih 268,2 juta, akan tetapi angka pengguna layanan operator ponsel sebanyak 355,5 juta pengguna. Hal ini berarti pengguna ponsel lebih 133\% dari jumlah penduduk atau dapat dipastikan hampir sebagian masyarakat memiliki lebih dari satu ponsel. Mengenai intensitas pengguna internet, masyarakat Indonesia termasuk aktif memanfaatkan internet setiap hari; 70\% dari 150 juta memanfaatkannya setiap hari, 14 $\%$ mengakses seminggu sekali dan sisanya menggunakan internet sebulan sekali. Terkait pemanfaatan internet, masyarakat Indonesia lebih memanfaatkan untuk mencari pengetahuan dan hiburan. Menariknya $98 \%$ pengguna memanfaatkan internet untuk menonton video online, sebanyak 50\% mengakses konten televisi, $46 \%$ memanfaatkan untuk game online, dan 36\% menggemari streaming. Mengenai penggunaan media sosial di Indonesia, ternyata 150 juta pengguna aktif internet sekaligus adalah pengguna aktif media sosial; dari jumlah ini yang mengakses lewat ponsel berjumlah 130 juta pengguna. Aktivitas lain selain mengakses informasi dan hiburan, pemanfaatan juga untuk bisnis dan perekonomian. Didukung oleh 
berkembangnya budaya populer, pemanfaatan media digital cenderung terus meningkat. Meskipun pada kenyataannya masih ada kesenjangan dari segi infrastruktur antara Indonesia bagian Timur dan Barat, namun secara menyeluruh teknologi digital terjangkau ke seluruh wilayah Indonesia. Data yang dilansir TDI ini tentunya dapat saja membawa pada kesimpulan bahwa masyarakat Indonesia adalah masyarakat digital. Akan tetapi mempertimbangkan beberapa daerah dengan fasilitas dan akses yang minim, masih ada sebagian kecil masyarakat yang belum mengenal dan memanfaatkan teknologi digital dan tentunya masih mengerjakan aktivitasnya secara manual ataupun mekanik.

Sinyalemen Schwab bahwa fenomena dan ciri dampak Revolusi Industri Keempat secara jelas sudah nampak dalam kehidupan bergereja di Indonesia. Pemanfaatan teknologi digital juga telah dilakukan oleh gereja-gereja di Indonesia. Pemanfaatan berupa internet, website, blog dan juga aplikasi-aplikasi media sosial seperti facebook, instagram, whatsapp, dan lainnya, sudah banyak dan bahkan sudah cukup lama digunakan oleh gereja. Meskipun pemanfaatannya masih berkaitan dengan kepentingan penyebaran informasi dan komunikasi, namun hampir sebagian besar gereja di Indonesia telah memanfaatkan teknologi digital. Pemanfaatan yang intens berkaitan dengan peribadahan gereja-gereja di Indonesia baru terlihat masif saat menghadapi pandemi Covid 19. Relasi fisik dan kehadiran beribadah secara in-person mendadak tergantikan dengan relasi online atau digital melalui aplikasi-aplikasi zoom, jitsi, meet, youtube chanel, whatsapp, dll. Pergeseran yang memaksa ini seolah-olah menggiring gereja-gereja memasuki "nature" atau dunia baru, terutama tatkala teknologi digital memberi ruang relasi virtual mengganti relasi fisik antar personal dan komunitas. Meskipun terkesan hanya memindahkan ruang komunitas fisik ke ruang virtual, namun dapat dirasakan bahwa peribadahan yang sekian lama cenderung merupakan hal privat, saat ini sudah menjadi bagian dari sektor publik dan digital. Kenyataan ini memberi gaung secara teologis bahwa gereja sedang dituntut untuk berteologi dalam konteks digital.

\section{METODOLOGI PENELITIAN}

Dalam rangka menjawab pertanyaan-pertanyaan penelitian di atas, penulis akan menggunakan pendekatan kualitatif dengan memanfaatkan sumber pemikiran 
dari buku, artikel dan tulisan jurnal baik tertulis maupun berupa data digital. Dalam rangka pembahasannya, penulis akan mengolah data dan informasi kualitatif tersebut dalam bentuk deskripsi, analisis dan refleksi. Diharapkan tulisan ini dapat memberi cara pandang tersendiri terhadap geliat bergereja dan teologi digital. Dalam deskripsi penulis akan menguraikan situasi yang mendorong adanya pergeseran paradigma oleh karena perkembangan peradaban termasuk perkembangan teknologi informasi. Selanjutnya menganalisis pemaknaan baru tentang sekularisasi dan tempatnya dalam kultur digital, mengaplikasikannya bagi teologi dan gereja, serta sejauh mana masyarakat sekarang memaknai pergeseran paradigma di atas. Penulis juga akan menguraikan pada bagian ini tentang aspek-aspek pokok dari perubahan paradigma serta sketsa model berteologi dalam era digital (termasuk eklesiologi dan misiologi). Dan pada bagian akhir, penulis akan menggambarkan kesimpulan dan pokok-pokok reflektif terkait topik ini, termasuk kemungkinan praksis iman dalam era digital. ${ }^{5}$

\section{HASIL DAN PEMBAHASAN}

\section{Sekilas Tentang Sekularisasi}

Kata sekularisasi adalah kata yang dihasilkan dari kata asal "sekuler". Menurut KBBI kata sekuler memiliki arti "bersifat duniawi atau kebendaan". ${ }^{6}$ Kata sekularisasi menunjuk pada sebuah proses perubahan berkenaan dengan perkembangan ilmu pengetahuan, teknologi dan sistem kemasyarakatan. Salah satunya adalah struktur pembentukan masyarakat Barat pasca Pencerahan dengan praanggapan yang non keagamaan (sekuler) dimana aktivitas kerohanian dipandang sebagai urusan individual. ${ }^{7}$ Banyak yang melihat peletak dasar paradigma baru mengenai makna sekulerisasi justru dari pemikiran Peter L. Berger. Dalam bukunya Under the Sacred Canopy, Berger melihat perubahan dari dominasi gereja di abad pertengahan yang berlanjut pada Pencerahan bergerak menuju modernisasi dan perkembangan rasionalitas, telah menghasilkan karya-karya yang menitikberatkan aspek kemanusiaan, kebebasan dan keadilan, maka ajaran gereja sebagai sumber pemikiran mulai ditinggalkan. Menyusul perkembangan tersebut muncullah upayaupaya membebaskan aspek sosial budaya dari dominasi simbol dan lembaga gereja. Perubahan sosial inilah yang disebut oleh Peter L. Berger sebagai sekularisasi. ${ }^{8}$ Dengan demikian sekularisasi adalah suatu kejadian sosial yang mengubah struktur, 
simbol, dominasi dan cengkeraman agama terhadap kehidupan sosial budaya suatu masyarakat.

Dalam bukunya The Secular City, Harvey Cox melihat bahwa sekularisasi sebagai sebuah pembebasan manusia dari proteksi agama dan metafisika, pengalihan dari alam lain. ${ }^{9}$ Cox menempatkan pandangannya terkait pusat dari modernitas adalah dunia dan bukanlah agama sebagaimana era sebelum Pencerahan. Cox juga memilah secara signifikan pengertian tentang sekulerisasi dan sekularisme. Baginya sekularisme cenderung merupakan ideologi yang tertutup, sedangkan sekularisasi mengarah pada membebaskan masyarakat dari kontrol agama dan pandangan metafisik yang tertutup (closed metaphysical worldviews). Dalam argumentasinya Cox melihat bahwa bobot teologi dari sekularisasi adalah penekanan bahwa sekularisasi berakar dari kepercayaan Alkitab. ${ }^{10}$ Pada taraf tertentu sekularisasi adalah hasil otentik dari implikasi kepercayaan Injil terhadap sejarah Barat. Sejalan dengan metode dan pemikiran yang sama, Charles Taylor dalam karyanya A Secular Age (2007), menguraikan tentang sekularisasi dan perkembangannya secara historis pula. Sebuah perkembangan dan perubahan yang diamati Taylor semenjak abad ke-15 di mana hampir tidak mungkin orang tidak percaya pada Allah dan keadaan di abad ke21 di mana tidak hanya nampak pertumbuhan ateis yang signifikan melainkan juga bertumbuhnya banyak alternatif dalam menyatakan iman. Dalam jejak sejarah ini Taylor memandang bahwa sekularitas adalah keseluruhan konteks pemahaman di mana semua sistem moral, spiritual dan pengalaman religius menempatkan diri. ${ }^{11}$ Taylor melihat perubahan sebagai revolusi religius semenjak kisah Reformasi yang ia sebut sebagai Reform Master Narrative, kemudian dua abad selanjutnya tatkala pemikiran Imanuel Kant yang menempatkan kesadaran individu sebagai unsur kunci moralitas, sehingga dari ranah sosio-kultural kini agama menjadi domain hubungan pribadi dengan Kristus. Selain itu, perubahan pada masa Pencerahan di mana aspek rasionalitas begitu kuat berpengaruh hingga legitimasi tatanan hierarki gerejawi dan politik mulai mendapatkan penolakan. Dalam konteks ini muncul penghayatan baru bahwa tujuan manusia untuk saling menguntungkan. Orientasi pertumbuhan dan kemakmuran menjadi nilai kunci. Bahkan perdagangan dan ekonomi dipandang sebagai "jalan menuju perdamaian". ${ }^{12}$ Dalam situasi ini menurut Taylor lahirlah “humanisme eksklusif” yakni sikap di mana pencapaian kebahagiaan manusia menjadi 
tujuan kehidupan dan pencapaian tujuan itu menjadi tanggung jawab eksklusif manusia sendiri; jadi tanpa acuan pada suatu realitas transenden. Hal ini mendorong sekularisasi semakin cepat teresapkan dalam masyarakat luas. ${ }^{13}$

Taylor memaknai mengurangnya dimensi Allah dalam arus sekularisasi ini sebagai perkembangan yang kontradiktif, artinya bahwa agama tidak akan menguap habis dalam sekularisasi. Agama dapat mempertahankan diri dengan menempatkan diri secara baru dalam dunia yang memang dianggap sudah bebas dari unsur-unsur ilahi, namun tetap ada kerinduan untuk sesuatu kekuatan di "luar dunia". Ini sebuah kecenderungan yang baru. Jadi ateisme bukanlah satu-satunya bentuk sekularisasi. Bagi Taylor masih adanya semangat dan tanggapan terhadap realitas transenden seperti ini menunjukkan bahwa itu sebuah realitas religius. Taylor melihat beberapa aspek penting dalam perkembangan sekularisasi. Pertama, terkait dengan pertanyaan mengapa manusia modern sulit percaya kepada Allah atau sebaliknya terkait materialisme ilmiah. Kedua, Taylor mengaitkan antara hubungan agama dengan kekerasan dimana ada mekanisme 'kambing hitam' atas nama agama. Ketiga, Taylor menguraikan tentang agama di zaman sekularisasi serta implikasi-implikasi dalam situasi baru bagi Kekeristenan. ${ }^{14}$

Dengan demikian menurut hemat penulis sekularisasi merupakan sebuah upaya memusatkan perhatian pada eksistensi manusia dengan semangat kebebasan namun tetap memberi ruang pada kesadaran transenden Yang Ilahi serta merujuk pada nilai kekeristenan. Franz Magnis-Suseno dalam tinjauannya terhadap buku Taylor ini memberikan pemahamannya sebagai simpulan bahwa sekularisasi merupakan sebuah proses yang kompleks, yang menggagalkan segala penjelasan sederhana dan linear. Alam sosial tersekularisasi sendiri adalah kompleks. Di suatu pihak alam ini merupakan puncak humanisme eksklusif warisan Pencerahan, di lain pihak eksklusivisme itu ditantang oleh suatu "kelaparan spiritual" yang tetap terarah pada "sesuatu" di luar dunia. Cerita dominan sekularisasi yang cenderung mempersalahkan agama-agama atas banyaknya kesusahan dunia, lama-kelamaan akan semakin tidak dipercaya lagi. ${ }^{15}$ Arah humanisme yang menjadi bagian dari sekularisasi menjadikan pemikiran tentang agama sebagai diskursus relasi dua arah yakni di suatu sisi agama masih bisa dapat dijadikan inspirasi hidup dan solusi atas problematika manusia dan di sisi yang lain pendapat yang meyakini bahwa manusia mampu menyelesaikan 
persoalan tanpa melibatkan agama. Pendekatan Taylor menurut Magnis-Suseno justru melihat berbagai perwujudan baru dari kedua pandangan di atas yang secara aktual dapat berfungsi bagi agama.

\section{Sekularisasi dan Kultur Digital}

Konsep humanisme eksklusif yang cenderung tiba pada titik pertanyaanpertanyaan spiritualitas sebagaimana digambarkan oleh Taylor inilah yang sedang bertumbuh dalam perkembangan budaya saat ini. Pemaknaan sekularisasi dalam kondisi mutakhir ini menunjukkan bahwa geliat agama untuk "menyesuaikan diri" justru hadir lewat wujud yang 'abstrak' yakni agama menempatkan perwujudan spiritualitas dan religiusitas sebagai bagian yang menandakan eksistensinya. Pikiran Taylor yang dilatarbelakangi oleh agama dalam konteks dunia Barat yang berhadapan dengan sekularisasi namun agama masih tetap eksis dengan wujud spiritualitasnya. Bagaimana dengan agama dan kebudayaan? Menurut hemat penulis, agama dan kebudayaan saat ini perlu dipahami dalam percampuran beberapa cakupan yakni paradigma baru sekularisasi, berkembangnya budaya populer, dan mewujudnya kultur digital akibat perkembangan ilmu dan teknologi digital. Percampuran ini adalah keterkaitan yang saling berkelindan dan menjadi konteks mutakhir masyarakat digital. Asumsi dasar dalam dunia digital melihat hal-hal baik seperti benda, makhluk, seni, ideologi hingga agama adalah terkait dengan data. Sekularisasi dan budaya populer, yang didukung oleh data dan pasar sebagaimana dalam teknologi digital menjadikannya sebagai kultur digital saat ini.

Kultur digital adalah sebuah istilah untuk menggambarkan situasi sosiobudaya mutakhir yang dalam tindakan dan interaksinya bergantung pada teknologi digital. Perkembangan teknologi digital yang pesat dan eksponensial adalah produk kerja sama antara "mind-computer interface” terutama program “deep learning” nya dengan teknologi nano dan rekayasa genetik sehingga mendudukkan data sebagai unsur sentral, ilmu kognitif sebagai peneliti kuncinya dan alat bantu digital yakni produk progresifnya (digital prosthetic technology). ${ }^{16}$ Dengan teknologi digital yang mengandalkan kecerdasan artifisial juga manusia semakin dipermudah untuk mengatasi masalah, jarak, komunikasi dan sekaligus menjelajah berbagai realitas dan batas konvensional perspektif. Karena itu realitas seolah menjadi “transparan”. Dunia 
manusia menjadi dunia tontonan visual yang dapat ditafsirkan oleh mesin digital untuk menjadi suguhan baru bagi kreativitas baru lagi. Bahkan menurut Sugiharto, manusia kemudian ditelan oleh "hermeneutika material-visual" sehingga tidak heran orang menganggap era digital sebagai bagian dari "post-humanis". ${ }^{17}$

Namun dalam kenyataannya kultur digital melahirkan banyak kontradiksi pula. Menurut Bambang Suguharto, ${ }^{18}$ kontradiksi itu antara lain; pertama, teknologi di satu sisi membuat terhubungnya semua komunikasi manusia dengan mudah, dapat menyatukan dalam suatu waktu yang sama namun berpotensi memecah-belah dan melahirkan polarisasi dalam masyarakat. Kedua, informasi yang masif dan cepat memberikan banyak variasi dan kekayaan informasi, namun karena sangat cepat berganti informasi maka pengetahuan yang didapat tidak mendalam (dangkal). Ketiga, variasi dan melimpahnya kekayaan informasi melahirkan kreativitas yang banyak, namun kreativitas tersebut juga tidak memiliki arah yang jelas. Disrupsi juga cepat sehingga pembaharuan sering kali tidak terprediksi. Keempat, kesadaran semakin tidak terikat pada realitas fisikal, mudah juga direkayasa termasuk melalui neurosciences. Nampak semakin spiritual tetapi sekaligus semakin material. Kelima, ketergantungan pada teknologi digital juga membuat individu selalu diberdayakan namun semakin mudah terperdaya bahkan tidak berdaya.

Berdasarkan gambaran mengenai kultur digital di atas maka dapat disimpulkan bahwa membaca realitas manusia dalam kultur digital perlu mempertimbangkan realitas yang didasarkan pada keunikan entitas, pemaparan data manusia yang masif dan cepat, pergeseran pada hakikat simbol-simbol teknologi yang menjadi dogma bagi realitas manusia, pentingnya pengalaman manusia sebagai penentu, penempatan nilai pada realitas dan konteks yang bersifat personal dan pertimbangan pada wujud-wujud dan nilai kontradiksi dari teknologi digital bagi kepentingan manusia. Pertimbanganpertimbangan ini menurut hemat penulis mesti menjadi acuan dan patokan dalam memperhatikan upaya berteologi dan pengembangan implementasi teologis dalam konteks kultur digital. Dari kenyataan seperi diuraikan dalam kesimpulan ini menunjukkan bahwa implikasi sekularisasi dalam kultur digital merupakan dua elemen yang saling berkelindan dan menyatu dalam membentuk realitas kekinian. Elemen-elemen agama dan keyakinan tentang agama masih berada namun perlu membentuk dirinya sedemikian rupa untuk mempertahankan eksistensinya dalam 
realitas sekularitas digital. Elemen spiritualitas dan religiositas merupakan bentuk eksistensi agama dalam konteks kultur digital yang tetap mencari "celah" perwujudan baru dalam wujud digital pula.

Dalam kaitan dengan hidup beragama, beberapa fenomena yang menarik dalam kultur digital ini perlu digambarkan sebagai contoh. Pertama, dalam interaksinya dengan tradisi, termasuk di dalamnya tradisi kekeristenan. Menurut Sugiharto, era digital adalah era yang menimbulkan suatu kenyataan mengenai posttradisi. Istilah post-tradisi dilahirkan berdasarkan situasi dalam tataran praksis kebudayaan terkini, di suatu pihak kebudayaan dianggap sebagai kunci pokok, namun dalam realitasnya, tradisi budaya di mana-mana semakin kehilangan daya ikat dan otoritas, akibat pola organisasi baru, jenis legitimasi baru dan kultur baru. Jadi pada kenyataannya sistem-sistem kebudayaan dan tradisi-tradisinya sedang berubah. Bersama dengan perubahan teknologi komunikasi dan digitasi penyebaran informasi, kebudayaan mengalami perubahan mendasar dalam karakter, penghayatan maupun pemaknaan. Sistem budaya menjadi sangat terbuka, saling berinteraksi, dalam transaksi tanpa henti, dan fluid/cair. Dalam kondisi ini tradisi bukan lagi satu-satunya pilar atau pusat gravitasi nilai yang paling menentukan. Kita dapat saja ditentukan oleh sistem pendidikan, sistem informasi, sistem ekonomi maupun sistem politik. Situasi inilah yang disebut post-tradisi. ${ }^{19}$ Sistem informasi digital saat ini dengan demikian menjadi pembentuk tradisi baru dalam kebudayaan dan kehidupan manusia.

\section{Masa Pandemic Covid 19 Sebagai Suatu Pengalaman "Penghayatan Baru"}

Pandemi Covid 19 telah membawa perubahan dalam cara hidup manusia. Manusia tidak lagi bisa menjalani pola hidup sebagaimana lazimnya. Perubahan terjadi di berbagai bidang kehidupan manusia juga meliputi pola kehidupan beragama. Standard berelasi dan berinteraksi antar sesama juga turut berubah secara signifikan. Bahkan kebiasaan termasuk cara beribadah juga turut mengalami perubahan dan penyesuaian. Dalam menanggapi kebijakan "physical" dan "social distancing" selama pandemi Covid 19, gereja-gereja di Indonesia terkhususnya GMIT, telah berupaya menerapkan beberapa kebijakan baru. Kebijakan itu meliputi; pertemuan dan rapat gereja dilakukan secara daring, peribadahan secara online, persembahan secara digital, pastoral bahkan Perjamuan Kudus secara online. Memang kebijakan ini sifatnya 
fleksibel mengingat konteks jemaat-jemaat di GMIT yang tidak semuanya memiliki fasilitas dan akses internet. Namun walaupun hanya bersifat temporer, situasi pandemi ini telah mengubah tradisi beribadah dan bergereja.

Keadaan "darurat" ini mestinya dapat saja dimaklumi mengingat pemahaman GMIT mengenai ibadah juga memberi ruang bagi peribadahan yang kontekstual. Dalam Pokok-pokok Eklesiologi GMIT peribadahan di GMIT dimaknai sebagai upaya mengembangkan spiritualitas jemaat dengan memelihara hubungan dan pengalaman bersama Allah dalam doa dan penyembahan, yang bertujuan untuk misi gereja dan memberi ruang bagi pengembangan peribadahan yang kontekstual. ${ }^{20}$ Namun terhadap kebijakan baru ini respon jemaat tidak luput dari sikap pro kontra dan polemik. Paling tidak, ada tiga varian pilihan yang dapat menjadi acuan pelaksanaan ibadah GMIT semasa pandemi Covid 19 yakni; pilihan untuk secara total bergereja online, bergereja dengan liturgi dan renungan tertulis yang disiapkan dan dibagikan ke setiap rumah tangga untuk beribadah, serta pilihan gabungan bentuk online dan tertulis. Kebijakan bergereja online di GMIT dilengkapi dengan beberapa dokumen panduan / standar operasional prosedur (SOP) pelayanan bergereja. ${ }^{21}$ Secara prinsip panduan-panduan pemanfaatan teknologi digital dalam masa pandemi Covid 19 dapat diterima hanya oleh beberapa jemaat saja yang sarana informasi dan komunikasinya memadai. Situasi pandemi ini dengan sendirinya telah "memaksa" gereja untuk berteologi dengan dunia digital. Belajar dari pengalaman tersebut, upaya gereja dalam memanfaatkan teknologi digital telah memunculkan beberapa hal pokok yang dapat dipandang sebagai tema kajian teologis.

Pertama, relasi dan interaksi. Dengan diadakannya ibadah atau bergereja secara online sebagai ganti bergereja yang lazim dalam gedung kebaktian, telah mengakibatkan berkurangnya interaksi fisik antar anggota komunitas gereja maupun dengan presbiter. Dampak physical dan social distancing di masa pandemi membuat aktivitas dan interaksi peribadahan menjadi bersifat individual, setiap umat berefleksi sendiri-sendiri melalui media digitalnya. Fenomena ini menurut Sherry Turkle akan bermuara pada pembentukan identitas di dunia maya. "Alone together", atau sendiri di tengah kebersamaan, istilah yang dipakai Turkle untuk menjelaskan posisi individu dalam ruang digital. ${ }^{22}$ Suatu posisi tentang kehadiran yang dibatasi oleh bilik digital yang sebenarnya sendirian namun dapat menjadi bersama dalam bilik digital. 
Kedua, ruang publik digital. Dengan memanfaatkan teknologi digital, aktivitas dan pelayanan gereja semakin nampak pada ruang publik, terutama ruang publik digital. Ketika ruang sosial beralih pada tataran digital maka berteologi dengan sendirinya menjadi ranah yang terbuka di ruang publik juga. Kehadiran di ruang publik tentunya memiliki konsekuensi secara teologis. Ruang publik menurut Emanuel Gerrit Singgih memiliki tiga cakupan yakni pasar (ekonomi dan globalisasi), negara (politik demokrasi/desentralisasi), dan komunitas (agama/budaya dan kontekstualisasi). ${ }^{23}$ Ruang publik dalam pembahasan tulisan ini lebih dominan mencakup ranah komunitas dan pasar. Keterbukaan di ruang publik ini tentunya memiliki imbas dan resiko tersendiri. Individu bahkan komunitas memiliki tanggungjawab moral tersendiri tatkala berada di ruang publik digital. Pemanfaatan teknologi di ruang publik digital disuatu sisi menjawab kebutuhan berteologi dan pelayanan gereja, sekaligus menjadi wadah menyatakan kabar baik kepada masyarakat umum namun di sisi yang lain, aktivitas keberagamaan akan berhadap-hadapan juga dengan aktivitas sekuler, cyber crime, hoax dan berbagai bentuk penyalahgunaan media digital lainnya.

Ketiga, sekularisasi dan makna baru sekuler. Pemahaman sekuler sering dimengerti sebagai pemisahan dan pemilahan urusan agama dengan urusan bernegara atau ranah pribadi dan ranah sosial. Teknologi digital termasuk juga aplikasi dan kontennya yang selama ini cenderung dimaknai sebagai hal sekuler yang digunakan untuk aktivitas kehidupan manusia, saat ini menjadi bagian yang dimanfaatkan juga oleh gereja. Aktivitas di ruang publik mesti bersedia berhadapan dengan kritik dan cara pemanfaatan yang negatif dan keliru dari teknologi digital. Aktivitas di ruang publik tidak luput dari reaksi sekuler. Dalam situasi ini maka makna kesakralan perlu dipahami secara baru. Kesakralan justru adalah apa yang ditunjukkan oleh hidup sehari-hari, saat manusia berinteraksi dengan yang lain.

Pengalaman beribadah dan bergereja online di masa pandemi ini dapat disebut sebagai "Penghayatan baru". Penghayatan baru ini tidak luput dari keragu-raguan, polemik dan kritik dalam gereja. Topik yang menjadi bahasan diskusi serius di kalangan awam maupun pendeta GMIT adalah pemberlakuan Perjamuan Kudus yang dilakukan secara online. Himbauan agar pelaksanaan Perjamuan dapat dilakukan di rumah-rumah dengan memberi ruang bagi kepala keluarga sebagai anggota sidi senior 
supaya menjadi pemimpin sakramen ternyata banyak ditolak oleh jemaat. Landasan teologis dan tradisi perjamuan di GMIT yang sekian lama bersifat pendeta/presbitercentris, mengakibatkan jemaat menuntut agar pelayanan Perjamuan dilakukan oleh pendeta atau presbiter di tiap-tiap rumah jemaat. Teologi jemaat yang bersumber dari tradisi seolah-olah berlawanan atau sekarang berhadap-hadapan langsung dengan arahan tata cara baru yang disiapkan majelis sinode. Meskipun arahan dikaitkan dengan situasi kebencanaan serta mengacu pada landasan teologis "imamat am orang percaya" namun perbedaan sikap masihlah nampak dalam praktek.

Begitu pula model peribadahan daring/online, pada kenyataannya masih perlu juga disiapkan model khusus (liturgi dan khotbah tertulis) bagi jemaat yang tidak memiliki akses dan fasilitas digital online. Mengenai persembahan jemaat secara digital pun dalam tataran praktik terjadi polemik dan diskusi yang panjang. Tidak semua jemaat dapat menerima model transfer bank sebagai alternatif baru. Pemahaman tradisional bahwa persembahan harus dibawakan ke "Rumah Tuhan" (dan diletakkan sendiri dalam kotak persembahan) merupakan sikap yang sulit berubah. Sikap responsif jemaat seperti ini tentunya perlu dengan bijak dipahami. Peralihan dari tradisi bergereja sebelumnya menuju bergereja secara online mempengaruhi bentuk penghayatan jemaat terutama mengenai tata cara dan makna teologis dari ibadah atau ritual. Dengan demikian, penerapan gereja digital di masa pandemi covid 19 memberikan sebuah sketsa relasi digital bergereja pada masa mendatang.

\section{Teologi Inkarnasi - Relasional dan Iman yang Dinamis}

Keith Anderson melihat gagasan relasi online di era digital dari kerangka teologi inkarnasi. Bagi Anderson, konsep Firman menjadi daging (Yohanes 1:14) dipandang sebagai keyakinan sentral dalam iman Kristen yang mewujud kehadiran Allah di tengah manusia dan hidup bersama manusia, meliputi seluruh aspek kemanusiaan manusia. Perjalanan, pengajaran, pelayanan dan apa yang Yesus kerjakan hingga kematian dan kebangkitannya menjelaskan bahwa dalam bentuk kehadiran fisik Yesus dapat masuk pada seluruh aspek kemanusiaan bahkan 'wilayah' yang terlupakan dan terabaikan sekalipun Ia hadir. Di sana Ia memulihkan, mengajar, memberi makan dan menyembuhkan serta mengampuni. Bahkan tradisi Perjamuan 
Kudus memelihara pemahaman dan keyakinan penjelmaan Kristus lewat roti dan anggur. Menurut Anderson, tatkala layar "screen" dapat saja menjadi ancaman pemisah dan mendigitalkan hubungan antar manusia maka semakin penting untuk menggunakan "logika inkarnasional” Kristen sebagai upaya perlindungan terhadap ketergantungan pada perangkat digital semata. ${ }^{24}$ Sebagai hasil karya pengetahuan manusia, teknologi pada dasarnya bersifat netral. Teknologi digital memiliki sifat membantu tetapi dapat pula dipergunakan sebagai sesuatu yang menghambat, diciptakan untuk merekatkan relasi namun juga dapat merenggangkan relasi. Teologi inkarnasi jelas mengedepankan relasi dan menjunjung kemanusiaan manusia sebagai wadah kehadiran Allah.

Pemahaman inkarnasi dalam makna relasional ini turut digaungkan oleh Andrew Root. ${ }^{25}$ Ia melandaskan pemikirannya tentang inkarnasi dari pemikiran Dietrich Bonhoeffer bahwa Yesus sebagai inkarnasi Allah berarti Allah ada di dunia sehingga manusia dapat bertemu dengan Tuhan tanpa harus berpaling dari dunia. Bagi Root, inkarnasi dapat dilihat sebagai strategi atau rencana Allah ketika inkarnasi dibahas dalam kaitan bentuk pelayanan relasional. Sering kali inkarnasi dipandang sebagai alat memengaruhi orang. Pemahaman ini mengarahkan pada asumsi bahwa menjadi inkarnasi berarti hadir sedemikian rupa sehingga dapat memperoleh pengaruh dan mempengaruhi orang lain, seolah-olah Allah di surga telah menetapkan inkarnasi untuk mempengaruhi manusia. Konsep ini menurut Root, dibantah oleh Bonhoeffer. Bagi Bonhoeffer inkarnasi bukanlah untuk mempengaruhi melainkan tentang solidaritas dalam kemanusiaan. ${ }^{26}$ Dengan demikian, inkarnasi menempatkan hubungan relasional kemanusiaan sebagai hal yang utama.

Dengan pemahaman inkarnasi sebagaimana dijelaskan, maka gereja perlu mengembangkan pelayanan relasional. Relasional melintasi batas dunia fisik dan maya, maupun relasional lintas kategorial internal gereja. Inti dari pelayanan relasional adalah membawa setiap pribadi jemaat menjadi manusia yang otentik. Otentisitas dalam konteks ini adalah menghargai dan memberi ruang pengalaman setiap individu dalam pengenalannya dan perjumpaannya dengan Yang Ilahi. Aspek dogmatis, ajaran dan tata gereja tidak dikesampingkan namun tidak lagi menjadi penekanan yang dominan. Pelayanan relasional berarti menjadi bagian dari umat dalam solidaritas penuh dengan kemanusiaannya dan membantu mereka menghindari 
dan melawan apa yang tidak manusiawi serta membantu mengklaim kemanusiaan mereka dalam ibadah dan pelayanan kepada Tuhan dan sesama. Dalam teologi digital pelayanan relasional turut menjadi bagian penting. Ruang digital sebagai wadah perjumpaan tidak membatasi relasi dan aktivitas antar sesama individu. Kehadiran secara digital maupun physical sama-sama mengandalkan solidaritas kemanusiaan sebagai bagian dari inkarnasi. Dalam konteks kehadiran di ruang publik, prinsip solidaritas inkarnasi yang sama perlu menjadi pegangan di samping penekanan aspek kebaikan dan keindahan sebagaimana yang disampaikan oleh Bagus Laksana.

Model inkarnasi adalah model yang turut menanggapi perubahan. Konsep Allah yang hadir dalam setiap perubahan termasuk perubahan karena covid 19 juga dikemukakan oleh Andreas Yewangoe. Menurut Yewangoe iman Kristen tidak statis dan picik. Dalam pandemi covid 19 bagaimana menjalin relasi dan beribadah sudah sangat ditentukan oleh virus ini. Apa yang disebutkan sebagai "digital dictatorship" (kediktatoran digital) sekarang telah kita alami. Namun menurutnya kita beruntung karena iman Kristen adalah iman yang dinamis. Iman yang terbuka pada perubahan. Allah adalah Allah perubahan. Pendapat Yewangoe yang dimuat pada fanpage Facebooknya merujuk pada pendapat H.M. Kuitert yang menyatakan :

"Kekristenan berjalan bersama waktu, ia tidak terpaku pada asal-muasal
agrarisnya. Tidak perlu semuanya dipegang sebagaimana begitu dahulu.
Karena itu kekristenan juga mempunyai kata untuk suatu budaya teknologi
atau yang bersifat kota. Juga untuk orang-orang yang telah belajar untuk
terus mempertanyakan secara kritis agama mereka. Kekristenan juga
mempunyai kata bagi manusia yang bekerja membangun dunia mereka.
Bahwa memang sejarah belum selesai, berarti bahwa lanjutan (dari sejarah
itu) juga tergantung pada apa yang kita ciptakan. Maka iman Kristen adalah
iman yang terwujud dalam upaya untuk mewujudkan dunia yang lebih baik.
Karena itu (iman Kristen) mengenal penderitaan dan perjuangan, keragu-
raguan dan kadang-kadang keputusasaan. Barangsiapa yang sungguh-
sungguh memprihatinkan keselamatan manusia, akan terus menderita dan
berjuang selama tidak ada air mata yang tidak perlu dicurahkan." 27

Dengan demikian teologi inkarnasi yang menempatkan hubungan relasional kemanusiaan yang dijalankan oleh iman dinamis merupakan dasar pijak berteologi dalam konteks digital. Konsepsi ibadah online dan alternatif-alternatif yang bersifat fleksibel sebagaimana yang dilakukan oleh GMIT dapat menjadi profil dari "penghayatan baru” sebagai respons pada konteks dan realitas digital. 


\section{Eklesiologi Yang Cair Digital}

Dalam rangka mengembangkan kehidupan meng-gereja yang menjawab model relasional secara digital maka perlu dikembangkan model eklesiologi yang cair. Perspektif yang mau dikembangkan ini bukanlah dalam rangka mempertentangkan dengan model gereja solid. Pete Ward mengawali gagasan tentang gereja cair dengan gambaran imajinatif tentang bagaimana beranjak dari cara memandang gereja sebagai kumpulan orang dalam suatu tempat, menuju gagasan gereja dengan berbagai rangkaian relasi dan komunikasi. Gambarannya lebih pada sebuah "network" daripada pertemuan ("assembly"). ${ }^{28}$ Pengertian gereja yang cair menurut Ward sebagaimana yang dikemukakan Handi Hadiwitanto, lebih berkaitan dengan sikap gereja yang mampu hidup di tengah perubahan masyarakat termasuk masyarakat modern, yang hidup secara cair dengan menangkap hal-hal inti yang baik di tengah berbagai perubahan. Karena itu gereja yang cair lebih mengembangkan kemampuan berelasi dan berkomunikasi dengan konteks kekinian demi mempertajam tanggung jawab gereja maupun masyarakat secara umum. ${ }^{29}$ Dengan demikian aspek cair berkenaan juga dengan sikap responsif dan inovatif gereja terhadap hal-hal yang baru dan sedang berkembang sekaligus membangun refleksi dan aksi yang konkrit terkait realitas yang ada.

Dalam konsep gereja cair peran umat dalam berakselerasi sebagai orang-orang beriman diberi ruang yang luas. Hierarki dan struktur bersifat sebagai pelancar, dan ruang terbuka bagi inisiatif yang bertanggung jawab dari umat. Menurut Rodger Nishioka sebagaimana dikutip Joas Adiprasetya, bahwa "gereja cair mencakup ambiguitas, misteri, ketakjuban dan kekaguman. Gereja cair hidup dengan mudah dan nyaman dengan paradoks dan ironi dan nilai lebih dari sekedar ketertiban. Gereja cair bersifat encer dan lincah, serta menanggapi tekanan-tekanan bahkan menyambut semuanya itu karena hal ini merupakan hakekat kehidupan. Gereja cair tidak memagari umatnya, melainkan merangkul mereka-mengakui rasa sakit dan penderitaan serta kesedihan dan kegelisahan. Gereja cair bersifat responsif dan tidak beranggapan bahwa orang berpikir dengan cara yang sama atau harus berpikir dengan cara yang sama. Ada juga klaim kebenaran universal di gereja cair namun kebenarankebenaran ini tidak berasal dari hierarki institusi melainkan datang dari kehidupan komunitas. Pendeta bukanlah yang memegang kendali di gereja cair. Pendeta tidak 
lagi menjadi penerus pengetahuan tetapi lebih menjadi pemandu bagi peziarah dan saluran bagi Roh Kudus". ${ }^{30}$ Dengan demikian, fungsi pelancar pada pendeta bertujuan memfasilitasi umat untuk dapat mengaktualisasikan iman secara bertanggung jawab termasuk dalam ruang digital.

\section{Sketsa Gereja "Cair Digital"}

Dengan konsep dan sifat gereja cair sebagaimana dijelaskan di atas maka pokok-pokok pergumulan berkaitan pelaksanaan "gereja online" dapat disikapi dengan cara memberi ruang pada sikap responsif jemaat. Sebagai institusi menyediakan alternatif pilihan dan kajian teologis juga perlu disertai dengan keterbukaan pada apa yang bertumbuh dan berkembang dalam jemaat. Aspek "ecclesia discens" gereja oleh karena itu mesti lebih berperan sembari membantu memahami inisiatif jemaat. Hadiwitanto merangkum dua faktor utama dalam mengembangkan gereja cair yakni mengupayakan komunikasi yang baik dan menghargai sekaligus mengembangkan elemen otentisitas jemaat. ${ }^{31}$ Komunikasi yang dimaksud adalah komunikasi yang menghargai relasional dan mendengarkan semua elemen gereja termasuk kelompok "digital native" maupun "digital immigrant". Sedangkan otentisitas adalah upaya memberi ruang bagi pengalaman jemaat yang membentuk spiritualitasnya termasuk "teologi operatif" mereka di dalam ruang komunitas.

Dengan hakikat gereja cair sebagaimana diuraikan, maka konsep gereja "cair digital" perlu dikemukakan. Konsep cair digital dapat dikembangkan dengan memperhatikan beberapa kondisi; Pertama, mengupayakan dan mengembangkan fasilitas dan akses digital serta sistem informasi dan komunikasi digital yang didukung oleh sumber daya manusia yang memadai, yang dapat menuntun umat untuk bergereja secara online. Kedua, membangun relasi dan komunikasi secara online dengan mengutamakan komunikasi yang etis dan bertanggung jawab. Ketiga, mengupayakan jejaring secara online sebagai sarana komunikasi dan informasi. Wujud dari bentuk online ini bisa berupa group jejaring kategorial, group jejaring presbiter dan jemaat, group jejaring pelaksana tugas organisatoris, atau komunitas-komunitas virtual gerejawi termasuk dalam pelayanan relasional kategorial dan fungsional (vocal group dan paduan suara). Untuk mendukung konsep liquid digital ini, gereja juga dapat 
menciptakan aplikasi dan program khusus yang dapat diakses oleh jemaat. Ketiga, perlu juga dikembangkan model komunikasi privat secara online yang memberi ruang pelayanan pastoral serta mendengar masukan dan cerita dari jemaat. Keempat, terkait dengan sisi otentisitas sebagai aspek yang penting dalam gereja cair maka bentukbentuk ekspresi iman jemaat yang tertuang dalam ruang digital dapat sikapi secara pastoral bagi penguatan dan pengembangan iman jemaat.

Karena itu orientasi tugas gerejawi atau di GMIT disebut Panca Pelayanan; Koinonia, Marturia, Diakonia, Liturgia dan Oikonomia/Penatalayanan yang sifatnya institusional organisatoris, dan mengandalkan struktur, rasanya perlu dievaluasi kembali, terutama dalam rangka mengedepankan komunikasi dan otentisitas jemaat sekaligus membangun landasan bergereja secara digital. Tentu melihat upaya-upaya yang sudah dilakukan oleh Majelis Sinode GMIT sepanjang masa pandemi COVID19 ini patut diberi apresiasi, terutama dalam menuntun dan mengawal umat untuk menjalani protokol kesehatan sebagaimana yang diharapkan. Namun untuk membawa lebih ke dalam upaya berteologi dengan konteks digital adalah kerja yang terus dibangun. Wacana kritis teologis terkait gereja digital perlu dikomunikasikan secara matang dan mengupayakan kajian-kajian yang dapat mendukung GMIT menghadapi realitas dan konteks baru ini.

\section{Sketsa Misi sebagai Presensia dan "Accompaniment”}

Jika teologi inkarnasi dan iman dinamis sebagai landasan, serta konsep gereja cair digital yang mengedepankan komunikasi dan otentisitas adalah eklesiologi yang perlu dikembangkan maka misi yang berkenan dikembangkan dalam konteks digital ini adalah misi sebagai Presensia ${ }^{32}$ dan “accompaniment”/berjalan bersama.

Dalam memaknai misi sebagai presensia, dunia digital tidaklah dipandang sebagai "teritori" baru. Kata teritori memiliki bias misi kolonial sementara dalam perkembangan misi kontemporer, ciri-ciri ekspansif sudah perlahan ditinggalkan. ${ }^{33}$ Menurut Singgih, misi sebagai Presensia dipopulerkan oleh Arie de Kuijper dalam bukunya Missiologia. Model ini mengedepankan konsep gerak misi secara sentripetal sebagai spirit dari model presensia. Oleh karena itu, makna presensia tidak sematamata sebagai kehadiran secara statis melainkan kehadiran secara dinamis. Selain gerak misi sentripetal bertujuan lebih pada "kualitas" hidup beriman, gerakan dinamis dari 
model ini memandang seluruh aspek kehidupan dan keberadaan manusia sebagai wadah kehadiran Injil Kristus.

Karena itu Kuijper juga turut memperkenalkan "comprehensive approach" sebagai strategi misi untuk menghadirkan dan merelevansikan Injil. Comprehensive approach menurut Kuijper adalah pendekatan orang yang merangkumi segala bidang kehidupannya - pelayanan total dengan Injil total kepada manusia total. ${ }^{34}$ Menarik, karena implementasi pendekatan ini diuraikan secara konkret oleh Kuijper berupa; produksi dan penyebaran bacaan Kristen, termasuk penterjemahan, penyebaran dan penerangan Kitab Suci; kehadiran Kristen di dalam mass-media (bidang persuratkabaran, radio dan TV; tetapi juga perkunjungan rumah tangga, percakapan perorangan maupun mass-meetings. Di samping itu kegiatan dan pelayanan bagi mahasiswa; pelayanan kepada orang sakit, kepada orang miskin, kepada orang-orang yang menderita (yatim piatu, janda, invalide, a-sosial, gelandangan), pendidikan kaum awam maupun pendidikan theologia; dan juga minat terhadap persoalan agraria maupun persoalan urbanisasi. Di mana saja orang bekerja dan bergumul disitu Injil Yesus Kristus harus dihadirkan dan direlevansikan (presensia). ${ }^{35}$

Meskipun Kuijper menempatkan "manusia total” setara dengan 'Injil total", namun titik berat model presensia ini lebih kepada Injil, hal ini diakui oleh Kuijper. ${ }^{36}$ Karena itu, penulis menambahkan model accompaniment sebagai model pendamping dari presensia. Robert Schreiter dalam pengantar Dictionary of Mission menekankan bahwa konsep misi saat ini mengarah dengan pendekatan baru yang ditandai dengan kepekaan pada solidaritas dan pendampingan/"accompaniment". Dengan demikian profil misi pada era baru lebih digambarkan sebagai “ berjalan bersama” daripada "mengatur" dan "mengarahkan". ${ }^{37}$ Model accompaniment (berjalan bersama) adalah model yang menempatkan solidaritas kemanusiaan sebagai perhatian. Sebagaimana maksud inkarnasi yang memberi tempat bagi manusia dalam kemanusiaannya, model accompaniment memberi ruang relasional dan penghargaan pada siapa pun manusia.

Dalam konteks digital, gereja dengan demikian turut hadir dan berperan dalam ranah digital, bukan saja sebagai "user" yang sekedar memanfaatkan untuk kelancaran informasi maupun komunikasi, melainkan juga sebagai accompaniment/teman berjalan bersama dari umat. Bentuk-bentuk misi dengan model ini perlu diarahkan untuk mengakomodir pengalaman spiritual jemaat, membagi pengalaman-pengalaman 
yang bermanfaat, mengomunikasikan nilai-nilai Injil secara baru, menghargai relasi digital maupun fisik, mengakomodir kreativitas-kreativitas jemaat, serta mengedepankan kehadiran dalam ranah digital sebagai kehadiran Kristus.

Dalam tataran praktis, model accompaniment dapat diwujudkan dengan menciptakan aplikasi-aplikasi digital yang secara privat maupun komunitas dapat menjadi wadah komunikasi iman tanpa membeda-bedakan latar belakang jemaat. Selain itu, misi dapat menghadiri ruang-ruang komunitas virtual untuk mengembangkan komunikasi-komunikasi yang bertanggung jawab demi pengembangan jemaat dan nilai-nilai Kristiani, serta menumbuhkan spiritualitas jemaat. Untuk menghargai otentisitas dan kreativitas jemaat makan lewat media digital jemaat dapat dituntun untuk mengembangkan tugas gerejawi atau Panca Pelayanan GMIT.

\section{KESIMPULAN}

Teknologi digital telah membentuk peradaban yang mempengaruhi dan mengubah pola hidup manusia, termasuk kehidupan beragama. Sebagai realitas baru, gerak dunia digital perlu direspons secara teologis. Aspek sekularisasi, kultur digital menuntut geliat tertentu dari gereja dalam merespons konteks digitaal. Lewat bingkai teologi inkarnasi yang mengangkat pentingnya relasi dan identitas, penghayatan umat berkenaan dengan realitas digital dapat dipahami sebagai suatu upaya berteologi yang menjawab situasi ini. Ibadah online sebagai pengalaman bersama gereja-gereja di Indonesia telah menjadi sumber refleksi dan "pintu masuk" bagi pengembangan teologi digital di Indonesia. Pengalaman masa pandemi COVID-19 sebagai sebuah penghayatan baru, adalah cermin dan proyeksi tentang masa depan gereja dalam konteks digital.

Dunia digital menempatkan relasi dan komunikasi pada sisi yang penting. Karena itu praktek misi dan bergereja perlu mengalami perubahan sebagaimana konteks baru. Misi sebagai Presensia dan Accompaniment dalam model eklesiologi yang cair tentunya akan menjadi tantangan bagi gereja-gereja di Indonesia yang bingkai institusional organisatoris sangat kuat. Namun refleksi terhadap realitas baru, tidak pernah berhenti. Perubahan, semakin hari semakin mewujud pada perubahan yang baru. Realitas baru akan kembali muncul, sikap beriman selalu siap berdialog dengan 
perubahan. Tetap ada distansi tetapi bukan untuk menjauh, melainkan untuk memahami, kemudian melebur dan mengalir bersama menemukan Realitas.

GMIT adalah gereja dengan teritorial yang luas dan latar belakang jemaat yang beragam baik secara ekonomi, sosial dan budaya. Keragaman ini juga ditentukan oleh faktor pembangunan seperti fasilitas dan akses terhadap perkembangan teknologi informatika dan digital. Perkembangan peradaban digital di GMIT secara bertahap mulai dirasakan, karena itu GMIT perlu mempersiapkan dirinya baik secara fisik dan sarana maupun secara teologi. Secara infrastuktur baik hardware maupun software rasanya masih perlu diupayakan begitu pula secara teologis. Wacana teologi digital perlu menjadi perhatian GMIT, mendiskusikan dan mengedepannya secara matang terutama dalam rangka mengantisipasi masa depan berhadapan dengan realitas dan konteks digital.

\section{Endnotes:}

\footnotetext{
${ }^{1}$ Klaus Schwab, Revolusi Industri Keempat (Jakarta: Gramedia Pustaka Utama, 2019), 6.

2 Hendra Kusuma, "Nasib Penjaga Gerbang Tol Pasca Non Tunai," Detik News, 2019, https://finance.detik.com/berita-ekonomi-bisnis/d-4614214/nasib-penjaga-gerbang-tol-pasca-non-tunai. Contoh efisiensi akibat teknologi di Indonesia adalah ketika kebijakan pembayaran gerbang tol digantikan dengan pembayaran non tunai; cukup banyak pekerja yang diberhentikan

3 Fajar Pebrianto, "Riset: Belanja Online Meningkat Pesat Di Tengah Pandemi Covid-19 - Bisnis Tempo.Co," Tempo.co, 2020, https://bisnis.tempo.co/read/1331198/riset-belanja-online-meningkatpesat-di-tengah-pandemi-covid-19.

${ }^{4}$ Schwab, Revolusi Industri Keempat, 121.

${ }^{5}$ Steven J Sutcliffe and Ingvild Saelid Gilhus, New Age Spirituality: Rethinking Religion (New York: Routledge, 2014).

6 “Arti Kata Sekuler - Kamus Besar Bahasa Indonesia (KBBI) Online,” accessed December 29, 2021, https://kbbi.web.id/sekuler.

${ }^{7}$ Tony Lane, "Runtut Pijar: Sejarah Pemikiran Kristiani," Jakarta: BPK Gunung Mulia, 2007, 197.

${ }^{8}$ Peter L Berger, The Sacred Canopy: Elements of a Sociological Theory of Religion (New York: Doubleday \& Company, 1969), 107.

${ }^{9}$ Harvey Cox, The Secular City (Princeton University Press, 2013), 15.

${ }^{10}$ Sonny Eli Zaluchu, "Mengkritisi Teologi Sekularisasi," KURIOS (Jurnal Teologi Dan Pendidikan Agama Kristen) 4, no. 1 (2018): 34.

${ }^{11}$ Charles Taylor, A Secular Age (Mussachusetts: Harvard university press, 2007), 3.

12 Taylor, 180.

${ }^{13}$ Franz Magnis-Susesno, "Charles Taylor, A Secular Age, Cambridge, Mass./London: The Belknap Press of Harvard University Press, 2007, 874 Hlm.," DISKURSUS - JURNAL FILSAFAT DAN TEOLOGI STF DRIYARKARA 12, no. 1 (January 1, 2013): 127.

${ }^{14}$ Taylor, A Secular Age, 728.

${ }^{15}$ Magnis-Susesno, "Charles Taylor, A Secular Age, Cambridge, Mass./London: The Belknap Press of Harvard University Press, 2007, 874 Hlm.,” 130.
} 
${ }^{16}$ Bambang Sugiharto, Kebudayaan Dan Kondisi Post-Tradisi: Kajian Filosofis Atas Permasalahan Budaya Abad Ke-21 (Yogyakarta: Kanisius, 2019), 121.

${ }^{17}$ Sugiharto, 121.

${ }^{18}$ Sugiharto, 125-26.

${ }^{19}$ Sugiharto, 14.

${ }^{20}$ Pokok-Pokok Eklesiologi GMIT Ketetapan Sinode GMIT Istimewa No.1/TAP/SSI-GMIT/II/2010 dalam TATA GMIT, Majelis Sinode GMIT, Kupang, 2011, hal. 37

21 "SINODE GMIT - Gereja Masehi Injili Di Timor," accessed Agustus 30, 2021, https://sinodegmit.or.id/. Dalam kurun waktu Maret hingga Mei 2020, Majelis Sinode GMIT telah menetapkan beberapa kebijakan berupa panduan ibadah, Sakramen Perjamuan Kudus, dan persembahan Online.

${ }^{22}$ B Melkyor Pando and Widi, Hiruk Pikuk Jaringan Sosial Terhubung: Refleksi Filsafat Teknologi Atas Jaringan Sosial Terhubung (Yogyakarta: Kanisius, 2014), 80.

${ }^{23}$ Emanuel Gerrit Singgih, Dari Ruang Privat Ke Ruang Publik: Sebuah Kumpulan Tulisan Teologi Kontekstual Emanuel Gerrit Singgih (Yogyakarta: PT Kanisius, 2020), 376.

${ }^{24}$ Keith Anderson, The Digital Catedral: Networked Ministry in a Wireless World (New York: Morehouse Publishing, 2015), 86.

${ }^{25}$ Andrew Root, Revisiting Relational Youth Ministry: From a Strategy of Influence to a Theology of Incarnation (InterVarsity Press, 2007).

${ }^{26}$ Root, 88-91.

${ }^{27}$ https://m.facebook.com/story.php?story fbid=1219810915017255\&id=289861131345576 diakses 12 Juni 2021

${ }^{28}$ Peter Ward, Liquid Church (Oregon: Wipf and Stock Publishers, 2013), 2.

${ }^{29}$ Handi Hadiwitanto, Gereja Yang Cair: Sebuah Refleksi Singkat tentang Hidup Berkomunitas dan Pelayanan Lintas Generasi, Makalah dalam Seminar Gereja Cair di Jemaat GMIT Anugerah Kupang, 31 Januari 2019

${ }^{30}$ Meitha Sartika and Hizkia A Gunawan, Ecclesia in Transitu: Gereja Di Tengah Perubahan Zaman, Jakarta: BPK Gunung Mulia, 2018, 2.

${ }^{31}$ Handi Hadiwitanto, Gereja Yang Cair: Sebuah Refleksi Singkat tentang Hidup Berkomunitas dan Pelayanan Lintas Generasi, 5.

32 Singgih, Dari Ruang Privat Ke Ruang Publik: Sebuah Kumpulan Tulisan Teologi Kontekstual Emanuel Gerrit Singgih, 16-18.

${ }^{33}$ Singgih, 16-18.

${ }^{34}$ Arie D. Kuijper, Missiologia (Jakarta: BPK Gunung Mulia, 2016), 105.

${ }^{35}$ Kuijper, 105.

${ }^{36}$ Kuijper, 105.

${ }^{37}$ Karl Muller et al., Dictionary of Mission: Theology, History, Perspectives, (Maryknol NY: Orbis Books, 1997), xiii.

\section{DAFTAR PUSTAKA}

Anderson, Keith. The Digital Catedral: Networked Ministry in a Wireless World. New York: Morehouse Publishing, 2015.

“Arti Kata Sekuler - Kamus Besar Bahasa Indonesia (KBBI) Online.” Accessed December 29, 2021. https://kbbi.web.id/sekuler.

Berger, Peter L. The Sacred Canopy: Elements of a Sociological Theory of Religion.

New York: Doubleday \& Company, 1969. 
Cox, Harvey. The Secular City. Princeton University Press, 2013.

Fajar Pebrianto. "Riset: Belanja Online Meningkat Pesat Di Tengah Pandemi Covid19 - $\quad$ Bisnis Tempo.Co.” $\quad$ Tempo.co, 2020. https://bisnis.tempo.co/read/1331198/riset-belanja-online-meningkat-pesatdi-tengah-pandemi-covid-19.

Karl Muller, Theo Sundermeier, Sthephen B. Bevans, and Richard H Bliese. Dictionary of Mission: Theology, History, Perspectives,. Maryknol NY: Orbis Books, 1997.

Kuijper, Arie D. Missiologia. Jakarta: BPK Gunung Mulia, 2016.

Kusuma, Hendra. "Nasib Penjaga Gerbang Tol Pasca Non Tunai.” Detik News, 2019. https://finance.detik.com/berita-ekonomi-bisnis/d-4614214/nasib-penjagagerbang-tol-pasca-non-tunai.

Lane, Tony. "Runtut Pijar: Sejarah Pemikiran Kristiani." Jakarta: BPK Gunung Mulia, 2007, 126-28.

Magnis-Susesno, Franz. "Charles Taylor, A Secular Age, Cambridge, Mass./London: The Belknap Press of Harvard University Press, 2007, 874 Hlm.” DISKURSUS - JURNAL FILSAFAT DAN TEOLOGI STF DRIYARKARA 12, no. 1 (January $1, \quad$ 2013): https://doi.org/10.36383/diskursus.v12i1.124.

Pando, B Melkyor, and Widi. Hiruk Pikuk Jaringan Sosial Terhubung: Refleksi Filsafat Teknologi Atas Jaringan Sosial Terhubung. Yogyakarta: Kanisius, 2014.

Root, Andrew. Revisiting Relational Youth Ministry: From a Strategy of Influence to a Theology of Incarnation. InterVarsity Press, 2007.

Sartika, Meitha, and Hizkia A Gunawan. Ecclesia in Transitu: Gereja Di Tengah Perubahan Zaman. Jakarta: BPK Gunung Mulia, 2018.

Schwab, Klaus. Revolusi Industri Keempat. Jakarta: Gramedia Pustaka Utama, 2019.

Singgih, Emanuel Gerrit. Dari Ruang Privat Ke Ruang Publik: Sebuah Kumpulan Tulisan Teologi Kontekstual Emanuel Gerrit Singgih. Yogyakarta: PT Kanisius, 2020.

“SINODE GMIT - Gereja Masehi Injili Di Timor.” Accessed December 30, 2021. 
https://sinodegmit.or.id/.

Sugiharto, Bambang. Kebudayaan Dan Kondisi Post-Tradisi: Kajian Filosofis Atas Permasalahan Budaya Abad Ke-21. Yogyakarta: Kanisius, 2019.

Sutcliffe, Steven J, and Ingvild Saelid Gilhus. New Age Spirituality: Rethinking Religion. New York: Routledge, 2014.

Taylor, Charles. A Secular Age. Mussachusetts: Harvard university press, 2007.

Ward, Peter. Liquid Church. Oregon: Wipf and Stock Publishers, 2013.

Zaluchu, Sonny Eli. "Mengkritisi Teologi Sekularisasi." KURIOS (Jurnal Teologi Dan Pendidikan Agama Kristen) 4, no. 1 (2018): 26-38. 